\title{
Obturator Hernia With Meckel's Diverticulum In Hernial Sac
}

\begin{abstract}
:
Obturator hernia rarely occurs; it represents less than $2 \%$ of all abdominal hernias. It is a protrusion of the preperitoneal fat tissue or peritoneal defect through the obturator channel. Rule is that it is a disease of skinny, older women (seventh or eighth decades), usually multiparous, predominantly right-sided, usually incarcerated, rarely diagnosed preoperatively. The clinical diagnosis is rarely set due to the unclear signs and symptoms. Because of the delayed diagnosis the postoperative morbidity and mortality is significantly increased. CT of the pelvis is almost $100 \%$ accurate in the diagnosis of the obturator hernias and should be the modality of choice in elderly patients with the bowel obstruction of an unknown etiology. We report a case of a 70 -year- old woman who had been admitted to our department on several occasions due to the suboclusive problems and the obturator hernia with a Meckel's diverticulum was verified intraoperatively.
\end{abstract}

Keywords: obturator hernia, Meckel's diverticulum, computed tomography

\section{Igor Nović1 \\ Jovica Mišić ${ }^{1}$ \\ Predrag Lazić1}

${ }^{1}$ Department of General Surgery Public Health Institution Hospital "Sveti apostol Luka" Pop Ljubina bb, 7400 o Doboj Republic of Srpska Bosnia and Herzegovina

\section{Contact address:}

Jovica Mišić

Department of General Surgery

Public Health Institution Hospital "Sveti apostol Luka"

Pop Ljubina bb, 74000 Doboj telephone ++387 65-905-654 e-mail:misicjovo@yahoo.com

Submitted: May, 3rd, 2014 Accepted: May, 29th, 2014

\section{Case Report}

A 70-year-old woman was admitted to the surgical department with the clinical picture of ileus. She had been admitted to our department on several occasions due to the suboclusive problems and occasional abdominal pain. Then we did a CT and the abdominal ultrasound, but did not reveal the cause of the problems. The pain extended to the right hip and the right thigh; she was treated conservatively each time and sent home. This time, the native RTG of abdomen showed hydroaeric levels. We performed an emergency surgery, and a herniation of the small intestine through the obturator channel with a Meckel's diverticulum in hernia sac was diagnosed intraoperatively (Figure 1). Hernia sac was prepared and resected from the inside, and the resection of Meckel's diverticulum with a part of the small intestine was also performed, with the rapid postoperative recovery of the patient.

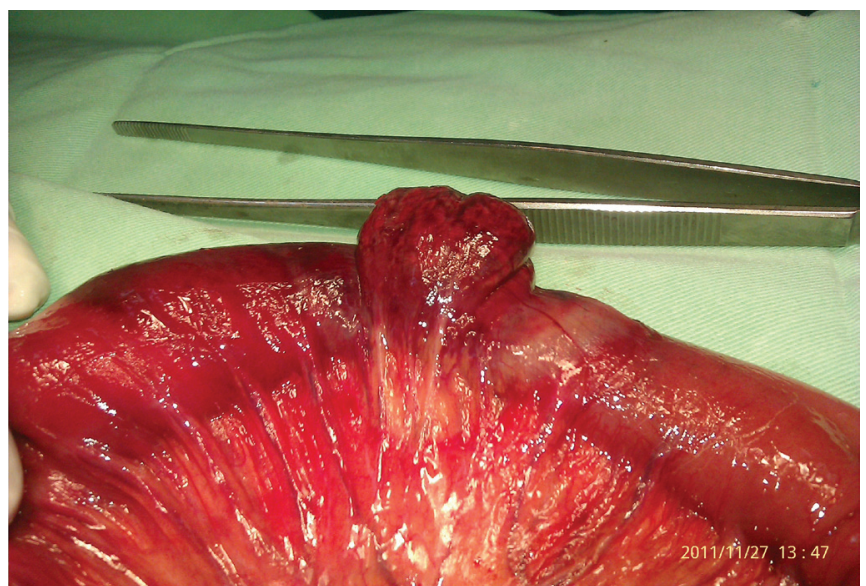

Figure 1. Meckel's diverticulum with a part of the small intestine"which was in hernia sac 


\section{Discussion}

Obturator hernias are rare, representing $0.07-1.41 \%$ of all hernias. Older women with chronic diseases are more susceptible to entrapment. Clinical findings are usually non-specific and a correct preoperative diagnosis is rarely placed on the basis of the clinical findings ${ }^{2}$. A lack of precise preoperative diagnosis leads to a delayed intervention, resulting in a high rate of bowel resection and the mortality greater than $25 \%$ in some studies ${ }^{3}$. Clinically, specific signs, such as Howship-Romberg sign (positive patellar reflex) or Hannington-Kiff sign (the loss of the thigh adductor reflex) are rarely present or not detected in these patients ${ }^{4}$. CT of pelvis with oral and iv contrast is a very useful diagnostic tool in cases of clinically indeterminate obstruction of the small intestine as well as in obturator hernias. CT shows classic signs of bowel obstruction through the foramen obturatum and was successful in all six cases of studies ${ }^{5}$. Another study also found that CT was $100 \%$ accurate in the diagnosis of obturator hernias ${ }^{6}$. Most of the research so far has revealed a closed small part of the bowel, especially the ileum, within the hernia sac.

Our case is unique because, apart from the small intensine, the content of the hernia sac was also made up of Meckel's diverticulum which was resected. Hernia sac was prepared and resected from the inside and with a rapid postoperative recovery of the patient the treatment was successfully completed.

\section{References}

1. Xiaoyan C, Xiangyang S, Xiujun C. Strangulated Intestinal Obstruction Secondary to a Typical Obturator Hernia: A Case Report with Literature Review 2012; 9(3):213-215.

2. Lesurtel M, Barret C, Champault G. Strangulated Obturator hernia. Preoperative diagnosis. J Chir (Paris) 1996;133(6):281-283.

3. Chung CC, Mok CO, Kwong KH, Ng EK, Lau WY. Obturator hernia revisited: a review of 12 cases in 7 years. J R Coll SurgEdinb 1997;42(2):82-84.

4. Yip AW, AhChong AK, Lam KH. Obturator hernia: a continuing diagnostic challenge. Surgery 1993;113(3):266-269.

5. Nishina M, Fujii C, Ogino R., Kobayashi R, Kumada K, Yamane K. Preoperative diagnosis of obturator hernia by computed tomography. Semin Ultrasound CT MR 2002;23(2):193-196.

6. Yau KK, Siu WT, Fung KH, Li MK. Small-bowel obstruction secondary to incarcerated obturator hernia. Am J Surg. 2006; 192: 207-208.

\section{Opturatorna kila sa Meckelovim divertikulumom}

\section{u kilnoj kesi}

\section{SAŽETAK:}

Opturatorna kila se rijetko javlja; predstavlja manje od 2\% svih abdominalnih kila. To je protruzija preperitonealnog masnog tkiva ili peritonealne kese kroz opturatorni kanal. Važi pravilo da je to oboljenje mršavih, starijih žena (sedma ili osma decenija), najčešće višerotki, pretežno desnostrana, obično inkarcerirana, rijetko preoperativno dijagnostikovana. Klinička dijagnoza se rijetko postavlja zbog nejasnih znakova i simptoma. Zbog zakašnjele dijagnoze značajno se povećava postoperativni morbiditet i mortalitet. CT karlice je skoro 100\% tačan u dijagnostici opturatornih hernija i treba da bude modalitet izbora kod starijih pacijenata sa opstrukcijom crijeva nepoznate etiologije. Prikazujemo slučaj 70- godišnje starice koja je u više navrata ležala na našem odjeljenju zbog subokluzivnih tegoba, a intraoperativno joj je verifikovana opturatorna kila sa Meckelovim divertikulomom u njoj.

Ključne reči: opturatorna kila, Meckelov divertikulum, kompjuterizovana tomografija 